УДК: 75.052

ББК: 85.14

A43

DOI:10.18688/aa166-4-30

Elisabetta Scungio

\title{
From Early Monasticism to Later Ascetism in Central Italy: Ascetic Life and Rock Art in the Grottoes of the Suppentonia Valley in Northern Latium between the $6^{\text {th }}$ and the $11^{\text {th }}$ Century
}

The Suppentonia valley is set in central Italy, exactly in Northern Latium (Viterbo province), about $50 \mathrm{~km}$ north from Rome, in an area that was anciently known as Ager Faliscus (Fig. 1). It is a wide valley, characterized by long and narrow gorges that progressively open going down to the river Tiber, reaching their largest extension in $700 \mathrm{~m}$ and their biggest depth in $200 \mathrm{~m}$ [3, p. 29]. The toponym is mentioned for the first time in the late $6^{\text {th }}$ century by Pope Gregory the Great in his Dialogues (book 1, chapters 7-8) referring to the monastery settled there called Subpentoma, because "ingens desuper rupis eminet" (i. e. "it hangs out on a precipitous crag") he explained [32, pp. 102-110]. Notwithstanding this, the etymology stays uncertain: several explanations of the term exist ${ }^{1}$, and it is definitely hard to comprehend if the valley took its name from the monastery, later dedicated to Saint Elias, or the monastery from the valley itself.

Anyway, the cenoby was not the first religious experience that exploited the natural mysticism of the site: its rocky countryside, its steep cliff faces, its wild nature and beauty, its silent isolation have always inspired an otherworldly atmosphere in the locals, who founded pagan shrines there, both in pre-Roman and Roman times [27, pp. 38-39; 279-287]. It is for the same reasons that - in conjunction with the spread of Eastern monasticism to Western Europe in the $4^{\text {th }}$ century - many hermits settled in the Suppentonia valley to live their secluded life. In most of the cases they reused abandoned preexisting grottoes, excavated in pre-Roman times mainly for funerary purposes, making few changes to adjust them for the new aim. Converting living and funerary rupestrian compartments into liturgical and/or monastic ones was typical of central Italy in Early Medieval times, especially in those areas whose geomorphological lay of the land allowed easy excavation. That frequently happened in Northern Latium where the ground is of volcanic origin, being mainly made of tuff, a stone friable but structurally stable

Scholars have proposed many explanations. The term Subpentoma could derive from the Greek number five $(\pi \dot{\varepsilon} v \tau \varepsilon)$, as that monastic community was one of the five Benedictine abbeys set in the environs of Rome [7, p. 111; 17, p. 55; 27, pp. 279-316]. The etymology of the name could also come from the position of the valley, placed at a lower level with respect to the city of Nepi - the capital of the Etruscan Pentapolis since the $6^{\text {th }}$ century B.C. - said Pentoma or Pentonia, sub Pentoma hence [4, pp. 11-12]. Finally, it could suggest a relationship of dependence with that same city, meaning sub Nepetoniam that the valley was part of its territory $[1$, p. 9]. 
at the same time. As a consequence, setting a date for such sites is definitely complicated, because of the continuous reuse and of the character of rock architecture itself, which misses welldefined building elements [28].

In the steep cliff walls of the Suppentonia valley tens of minuscule caves are still visible. According to the local oral tradition, two of them are recognizable as the ones occupied by holy anchorites Anastasius and Nonnosus. They lived in the $6^{\text {th }}$ century - as Gregory the Great reported in his

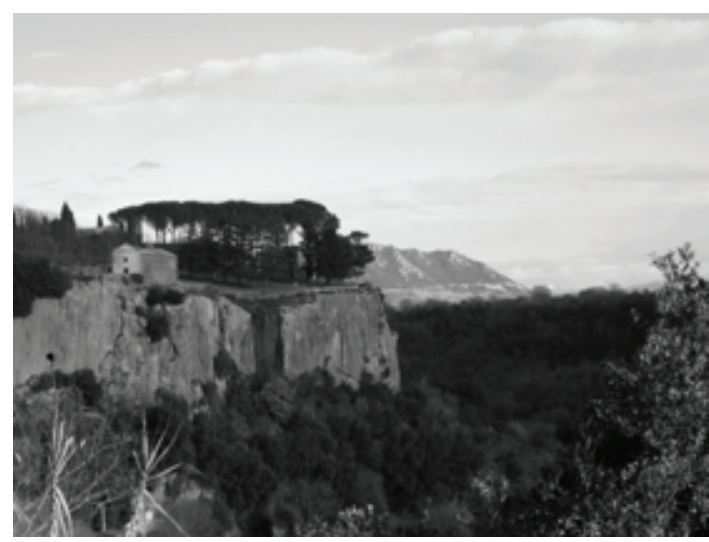

Fig. 1. Suppentonia valley. Castel Sant'Elia, Viterbo province, Italy Dialogues mentioned above - and they became abbots of the cenoby later settled in that same area, presumably an evolution of the original spontaneous ascetic occupation [32, pp. 102-110]. It seems, in fact, those mystics used to spend their everyday life separately, but then they temporarily left their hermitages to share prayer and worship with other fellows, following the semi-reclusive model of Syro-Palestinian monastic communities called lauras [3, pp. 31-32; 13]. Proof of this could be the presence of a three-room artificial cave, currently entitled to Saint Leonard, which looks to be used as a church being provided with some liturgical furnishings and parietal paintings ${ }^{2}$ (Fig. 2).

The grotto was dug on the southern side of the crag where the town of Castel Sant'Elia stands ${ }^{3}$. The access is throughout the most interesting room, on the eastern side (Fig. 3): it is a rectangular hall $(3.5 \mathrm{~m} \times 5 \mathrm{~m}$; height: $2.5 \mathrm{~m})$ provided with a semicircular apse (diameter: about $2 \mathrm{~m}$ long) on the right hand side - clearly added in a secondary moment partially excavated in the rock and built up with tuff ashlars. Next to it, on the left, there is a further semicircular arched recess (diameter: about $1.4 \mathrm{~m}$ ) placed over an altar, forming a sort of arcosolium. On top of the altar, a rectangular hollow communicates through a hole with an underlying niche dug on the front of its basement. Between the apse and the adjacent arched recess, a holy water font (diameter: $35 \mathrm{~cm}$; depth: $22 \mathrm{~cm}$ ) and a niche on a low pillar are shaped in the rock. The niche is to be interpreted as a shelf for liturgical tools and, for the same purpose two other niches must have been opened in the southern and in the northern sidewalls, as well (Fig. 4). Finally, on the western wall there is the doorway to enter the contiguous room, set on a square plan $(3 \mathrm{~m} \times 3 \mathrm{~m})$, where an oblong ditch in the north-western corner of the planking level, together with a niche in the same spot, and several holes in the ground are visible (Ill. 84). It seems that at first it was possible to enter this place from outside, since in its southern wall

2 Joselita Raspi Serra wrote the first scientific treatise about the site in the 1970s. From her study come all the measurements in the text [28].

3 The access to the grotto is now pretty comfortable, throughout a path recently opened on the occasion of the consolidation works (January 2012 - February 2013) carried out there. The architect in charge, Vincenzo Girolami, took care of the structural aspects, reinforcing the ceiling and the sidewalls of the rupestrian church; unfortunately, because of the lack of appropriate funds, the frescoes could not be restored [10]. 
there used to be an opening now walled up with blackspotted-red-tuff ashlars, in the middle of which a single lancet window stands. In its western wall a breach leads to the last and third portion of the grotto, that is an irregular room (about $4.5 \mathrm{~m} \times 2.4 \mathrm{~m}$ ) almost completely open to the outside by an arch on the southern side. In the bottom wall a burial recess with a protruding border opens; it

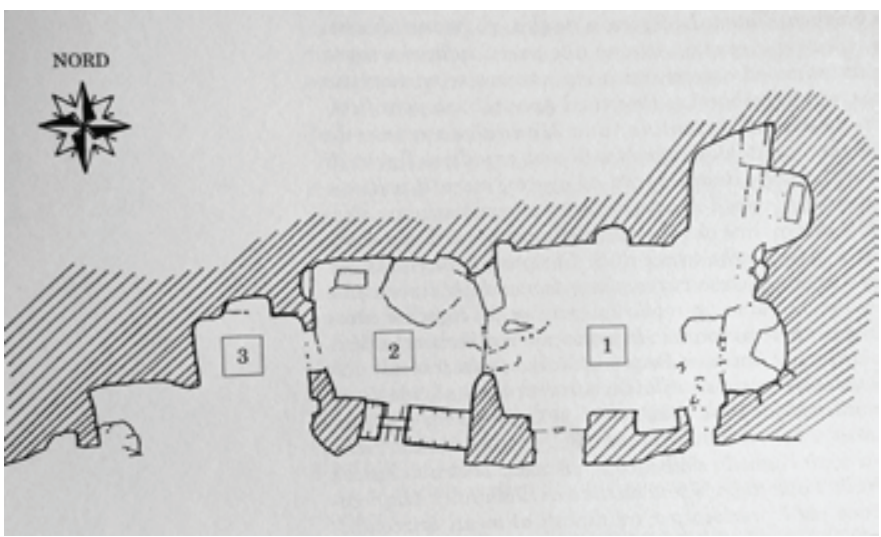

Fig. 2. Grotto of Saint Leonard. Plan. Castel Sant'Elia, Viterbo province, Italy presents a shape typical of sepulchers of ancient Ager Faliscus [28, p. 78] $]^{4}$.

Only the altar set in the first room can be helpful to propose a chronology. It was studied by Hartmann Grisar in the late 1800s [11, pp. 350-351]: according to the scholar, the altar was of a funerary kind, serving to hide the holy bodies usually kept in the nearby Saint Elias' abbey in case of danger, so frequent in the Early Middle Ages. This would explain the presence of a fenestella, i.e. the opening in the front of its basement, used to reach the relics placed inside: touching and worshipping them, in fact, was a traditional practice in Early Christian times, after the peace of Constantine [9, p. 437]. Grisar associated Saint Leonard's altar to a similar furnishing in the basilica of Saint Apostles in Rome, dated convincingly by him and by Charles Rohault de Fleury to the $6^{\text {th }}$ century $[29$, p. 137].

In accord with this early chronology and with the explanation of the function of the structure were also two local scholars, father Roberto Serra [31, pp. 30-33] and marquis Andrea Lezzani [15], who both described the site between the late 1800s and the early 1900s. In their writings they collected the oral tradition about the transfer of the remains of holy abbots Anastasius and Nonnosus from Saint Elias' monastery to the safer grotto of Saint Leonard by Pope Gregory the Great himself at the moment of the Langobardic invasion to Central Italy in the early $7^{\text {th }}$ century. However, this hypothesis cannot be accepted, since historical arguments proving it are missing. Those authors were probably influenced by the local belief which claims the pontiff left Rome to go northwards trying to stop the descent of the Langobards guided by king Agilulf, and met his wife, Teodolinda in person, in Saint Leonard's grotto. The pope would have persuaded the queen to intercede with her husband not to invade the city [31, p. 32] or - as it seems more probable - to cease the siege [24, p. 19].

\footnotetext{
4 Apart from the three-room grotto investigated here, there are two more openings in the cliff, proceeding westwards. They were clearly used for funerary purposes, one $(5 \mathrm{~m} \times 3 \mathrm{~m})$ characterized by series of rectilinear and circular niches - probably used to set cinerary urns in there - dug in its back wall, and the other housing a sort of a bed in its bottom wall, flanked by a recess ( $1 \mathrm{~m}$ long) on the north-western side [28, p. 78].
} 


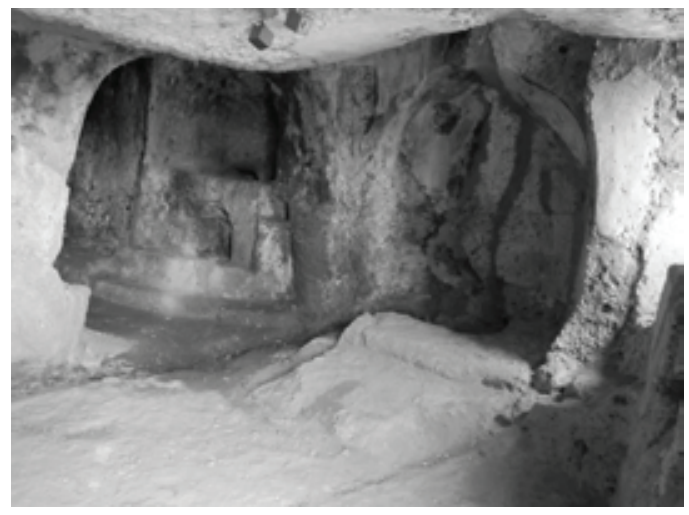

Fig. 3. Grotto of Saint Leonard. Eastern room, east side. Castel Sant'Elia, Viterbo province, Italy

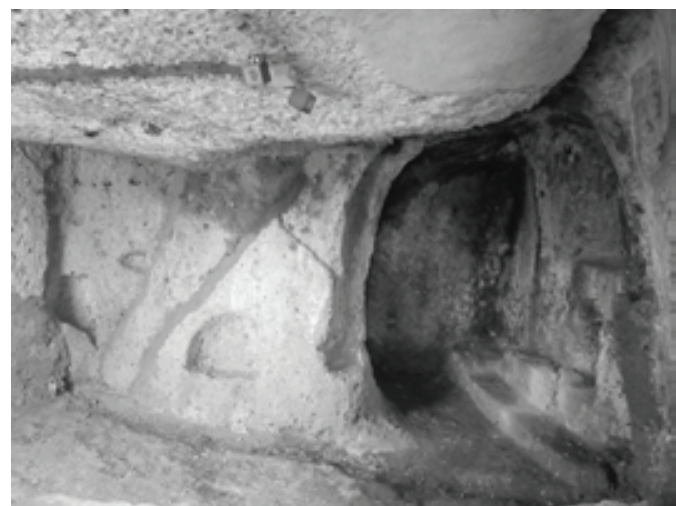

Fig. 4. Grotto of Saint Leonard. Eastern room, north side. Castel Sant'Elia, Viterbo province, Italy

At any rate none of the sources usually referred to about the legendary encounter provides a certain historical base, but only contributes to confirm the strategic value of the area in the defense of Rome at that time [2]. The main one is a chronicle written in the late $16^{\text {th }}$ century by Johannes von Nauclerus, who - besides living too late after the events narrated to be a reliable source - did not allude to the meeting at all. He reported that Pope Gregory the Great left the control of Rome to the praefectus urbi in order to go to the Nepesum (to be intended as the territory of Nepi, where Saint Leonard's grotto stood, or the dioceses set in the same town as well): together with the magister militum, they intended to fortify that area to stop Agilulf, who had already entered Etruria with his army [18, p. 623]. In the same way, it is relevant that Paul the Deacon - always so accurate in his Historia Langobardorum - did not mention the fact. The writer, effectively, just limited to outline the epistolary relationship between the pious queen and the holy pontiff; he focused on the important role she played for the conversion of her husband to Catholicism and for the stipulation of a resolute peace with the Pope himself and the Romans [33, pp. 348, 350].

What cannot be denied, on the other hand, is that there was a prolonged occupation of the site, testified by the fragments of wall paintings surviving thus far. The over mentioned reports by father Serra and marquis Lezzani are useful to reconstruct how the decorative scheme had to look like at first. At the end of the 1800s, in fact, eighteen figures were still visible, whereas nowadays we can barely see some scattered painted shreds.

Next to the entrance to the grotto, on the left hand side, the evanescent scraps of three bearded figures appear to the observer: they can be identified as saints, because of the halos on their heads. A geometric cornice with a meander is still running over them and under a portion of it, a further layer of painted plaster lays, which means, consequently, there used to be a previous decoration ${ }^{5}$. Beyond the doorway on the western wall, father Serra could observe three figures, one with "Eastern pontifical garments" he said (maybe a holy bishop),

As regards this part of the grotto, there is no specific description in the old reports. Maybe father Serra makes a reference to it, when he talks about five masculine figures - depicting prophets or apostles according to him - on a layer of compact plaster, but he did not give any further information about their exact location $[31$, p. 30]. 
a feminine image of Mary Magdalene or of the Virgin Mary, and one of Jesus Christ, depicted while blessing in the Byzantine way [31, pp. 30-31]. Today, only the bust of Jesus is clearly visible, even though just a half is preserved (like in the $19^{\text {th }}$ century actually), together with an orant of minor proportions on his right, recognizable for the position of the hand on one side (Ill. 85). Unfortunately, there are no more elements to identify it as a woman: one clue comes from the brown/violet cap painted on the head, which could be a credible remain of the veil or mitella usually worn by the Virgin Mary. This reading becomes more plausible if one considers on the opposite side, flanking the figure of Jesus Christ, there is enough space to think of a third figure, perhaps the whole scene depicting a Déesis [25, p. 49].

There are more painted shreds in the apse. On the left of the apsidal arch there used to be Saint John the Evangelist ${ }^{6}$, now inferable from an arm lifting a cartouche inscribed with the beginning of his Gospel "In principio erat verbum, et verbum erat aput (sic!) $D(e u) m$ "; thanks to the old reports it is possible to infer there was Saint John the Baptist on the opposite side, raising one arm up - like the Evangelist - towards the Mystic Lamb painted in the middle, on top of the arch [31, p. 31; 15, pp. 12-13]. It was a scene of acclamatio, usually painted on apsidal or ciborium arches in the Middle Ages ${ }^{7}[25$, p. 84]. As regards the apsidal conch framed by a triple-red-ochre-green stripe, like the surrounding arch - only one fragmentary figure still survives. It seems to be standing behind a barrier which covers it up to the knees: the character, who reveals to be an angel because of the wings, is painted on a blue and green background while turning toward the center and lifting his arms up in an attitude of deference. Once more, one of the old descriptions contributes to complete the missing elements: he was part of a composition including the Savior between two angels ${ }^{8}[15, \mathrm{p} .12]$.

Those exiguous remains were clearly retouched, as it is visible in the inscription and in the hand of the Evangelist. It is probable that the apse underwent a structural restoration - visible in the section built up in masonry - that also included an intervention on the painted decoration. Perhaps, that touch-up was made for the new consecration of the grotto in 1894, November $6^{\text {th }}$ (the memorial day of death of Saint Leonard), by Monsignor Sante Zanchi as vicar of the bishop of the dioceses [31, p. 32]. In any case, it is sure the rupestrian church underwent a restoration in the late 1800s by the Franciscan friars who had become the custodians of the close-by Sanctuary of Holy Mary ad rupes in 1892 [15, p. 12].

Thus, because of retouching and of bad preservation, only the angelic figure in the apsidal conch can be taken into stylistic consideration (Ill. 86). Its half-length depiction, partially

\footnotetext{
$6 \quad$ Nowadays, instead of the head of the Evangelist a regular rectangular blank is visible, since somebody deliberately cut away the plaster in that spot and stole it.

7 For instance, the same decoration can be found on an archivolt of the altar ciborium in the grotto of Saint Michael at the Mount Tancia (Rieti province) [25, p. 84]. That iconography occurred quite frequently in medieval Latium (e. g. Titulus Equitii at Saint Martin at the Mounts in Rome; Saint Mary in Vescovio at Torri in Sabina, Rieti province) and Campania (e. g. Saint Mary de Olearia in Maiori, Salerno province) [34, pp. 87-89].

Father Serra, on the other hand, asserted that the majestic figure of the Savior was flanked by Saint Peter, on the left hand side, and by the Virgin Mary, on the right hand side. He underscored how damaged those parietal paintings were and, perhaps, because of that situation he made a mistake in the interpretation of two of the characters [31, pp. 31-32]. The wings of the angel to the left are still clearly visible, so there is no doubt that the figure cannot depict Saint Peter. Today everything is lost of the angel to the right, but still in the 2000s Simone Piazza could see some traces of the second angelic figure [25, p. 49].
} 
covered by a balustrade, and the typology of its drapery, knotted on the waist and with $\mathrm{V}$-shaped-folds on the bottom, remind the analogous angel painted in a niche linked to an altar in a small chapel in the catacomb of Saint Hermes in Rome [25, p. 50], dating from the $11^{\text {th }}[8]$ or the $12^{\text {th }}$ century $[12 ; 16$, pp. $278-29 ; 19$, pp. 322-326]. Similarly, the large and spaced out brush strokes employed in Saint Leonard's can be found in the original shreds of the painted cycle in Saint Urban at the Caffarella in Rome [25, p. 112], variously dated throughout the $11^{\text {th }}$ century [30].

Considering these comparisons, it seems likely there was an update of the paintings of the small rupestrian church after the year $1000^{9}$; this could be explained as a consequence of the general renaissance asceticism experienced in Western Europe at that time, which took place in connection with the crisis of the monastic system. As a matter of fact, the enormous political and economic power gained by great abbeys, thanks to the Cluny Reform, caused the detachment from their institutions of many monks who wanted to rediscover the purity of monastic origins by living a simpler secluded life [14, pp. 204-209; 23, pp. 109-115; 26, pp. 48-51]. Considering this, it is fascinating to think how those paintings were laid out, or commissioned at least, by the same ascetics who attended the grotto in the $11^{\text {th }}$ century. Maybe one of them left his signature at the base of the apsidal conch by writing his own name there, in an inscription that could be partially seen at the turn of the $19^{\text {th }}$ century - as it is referred by marquis Lezzani — but today completely disappeared, that said “(...)CENTIUS PRE(sbi) TER MONA[c]H[us] [hoc opus fecit or fieri fecit]"10 [15, p. 12].

Finally, one more aspect is still to be taken into consideration, which is the reason why the rupestrian church is dedicated to Saint Leonard. On the southern wall, facing the entrance to the left, the remains of a huge painted figure, placed against a red background, are even now visible (Ill. 87): it is an isolated standing masculine body, having a halo on his tonsured head - a holy monk hence, - wearing an ochre habit on a white long-sleeve tunic, holding a white vertical shaft, maybe the base of a flag or a cross or a crosier in one hand, and a book in the other ${ }^{11}$. That character was recognized as Saint Leonard himself by marquis Lezzani $\left[15\right.$, p. 13], who could see some remains of the chains ${ }^{12}$, a typical attribute of him, being the patron of prisoners besides many other categories of devotees. Leonard lived in $5^{\text {th }}-6^{\text {th }}$ century Merovingian Gallia, and was close to king Clodoveus, thanks to whom he had the privilege to set the arrested free - hence the chains as one of his attributes - and founded the Monastery of Nobiliacum (now Saint-Léonard-de-Noblat in France, not far from Limoges), later becoming a hermit himself [5]. The painting is a separated votive panel, like many other ones that can be seen in central and southern Italian rupestrian churches - and not only - mainly painted in the $14^{\text {th }}$ century, when older painted cycles were added with

9 A different dating to the $6^{\text {th }}$ century has been proposed, based on the supposed chronology of the altar and of the first monastic occupation of the Suppentonia Valley, together with references to the classical monumentality of Antiquity and to Byzantine features due to a strong influence of Greek culture $[20 ; 21 ; 22]$. Nonetheless, these elements look to be too generic to prove such an untimely execution.

${ }_{10}$ The epigraph was written in white letters on a red stripe. Archaeologist father Giuseppe Bonavenia read it $[15, \mathrm{p} .12]$.

${ }_{11}$ These are all typical elements in the iconography of Saint Leonard [6].

12 At the present time some white brush strokes are still visible at a middle height on the figure. They have been interpreted as what remains of the chains typical of the saint [25, p. 51]. 
new scattered pictures: this chronology seems to be plausible for its typology and for its style, showing that figure with remarkable softness and brilliant colors [25, pp. 231-233].

The presence of such a saint is a further evidence of the prolonged occupation of the grotto as a church by the local community of anchorites who chose him as an exemplum and as a source of inspiration for their semi-secluded life.

Title. From Early Monasticism to Later Ascetism in Central Italy: Ascetic Life and Rock Art in the Grottoes of the Suppentonia Valley in Northern Latium between the $6^{\text {th }}$ and the $11^{\text {th }}$ Century.

Author. Elisabetta Scungio - Ph. D., teaching assistant. Sapienza University of Rome, Piazzale Aldo Moro 5, 00185 Rome, Italy. elisabetta.scungio@uniroma1.it.

Abstract. This article aims to investigate the early monastic occupation of the Suppentonia valley, set in Northern Latium (Central Italy), $50 \mathrm{~km}$ far from Rome. Thanks to the sources, it is known that many hermits settled there since the $6^{\text {th }}$ century, at least exploiting the isolation and the natural mysticism of the site. In fact, plenty of minuscule grottoes are still visible excavated in the tuff (the local volcanic rock) in the cliff sides, where anchorites - among them there were Saint Anastasius and Nonnosus, cited by Pope Gregory the Great in his Dialogues - used to spend their secluded life. It is highly probable that they shared common liturgy and prayer, just like in Syro-Palestinian monasteries (lauras), as it seems from the presence of a larger three-room grotto provided with liturgical furnishings and paintings, presumably a rupestrian church. This is commonly known as grotto of Saint Leonard, because of a painted votive panel depicting that holy hermit inside there. The altar in the grotto - opened by a niche for relics in its basement and covered by an arched recess - seems to be dating from the $6^{\text {th }}$ century. This early dating fostered a link between the church and the Langobardic invasion of the near-by area: a local legend reports that in the early $7^{\text {th }}$ century it was the place where Pope Gregory the Great met queen Teodolinda - king Agilulf's wife - trying to stop the descent to Rome of that people. Anyway, no historic evidence proves that fact really happened. In spite of this, there certainly was a prolonged use of the site, considering the painted shreds still surviving on the sidewalls. They can be dated to the $11^{\text {th }}$ century and probably they have to be put in connection with the great revival of ascetism all over Europe at that time, perhaps being made by the same hermits who settled there. Moreover, a later continuity of use of the site in the $14^{\text {th }}$ century is certain because of the painting depicting Saint Leonard, which can be dated to that time for its colors and style.

Keywords: Italy; Latium; Suppentonia valley; monasticism; ascetism; rock art; parietal paintings.

Название статьи. От раннего монашества к позднему аскетизму в Центральной Италии VI-XI веков: аскетический образ жизни и фрески пещер долины Суппентония в Северном Лацио.

Сведения об авторе. Скунджио Элизабета - Ph. D., ассистент. Римский университет Сапиенца, площадь Альдо Моро 5, Рим, Италия, 00185. elisabetta.scungio@hotmail.it

Аннотация. Статья посвящена проблеме заселения монахами пещер в долине Суппентония в Северном Лацио (Центральная Италия, в 50 км от Рима). Источники свидетельствуют, что отшельники появились здесь по крайней мере с VI в., облюбовав это место, изолированное положение и чудесная природа которого делают его столь подходящим для мистического самоуглубления. До сих пор в склонах скал можно видеть маленькие высеченные в местной вулканической породе пещеры, где анахореты - в том числе святой Анастасий и святой Нонн, на которых ссылается в своих «Беседах» Григорий Великий, - вели уединенную жизнь. Можно с большой долей вероятности утверждать, что отшельники участвовали в совместных богослужениях и молитвах, как это было в сиро-палестинских монастырях (лаврах). Об этом говорит наличие большого разделенного на три помещения грота, снабженного литургическими предметами и фресками. По всей видимости, это пещерная церковь. Она была названа «грот святого Леонарда» по найденной там вотивной створке, на которой изображен святой. Алтарь в гроте - с нишей для мощей в основании и закрытый с востока апсидой - может быть отнесен к VI в. Эта ранняя датировка заставляет связывать появление церкви с вторжением в область лангобардов. Местная легенда, которая, впрочем, не подтверждена историческими источниками, сообщает, что здесь в начале VII в. состоялась встреча папы Григория Великого и королевы Теодолинды - жены короля Агилульфа, - целью которой была остановка оттока местного населения в Рим (завоеватели лангобарды исповедовали арианство). Несмотря на это, сохранившиеся фрагменты фресок на стенах позволяют с уверенностью утверждать, что 
церковь продолжала использоваться в течение длительного времени. Фрески могут быть датированы XI в., и, вероятно, их создание обусловлено подъемом аскетического движения в Европе в это время. Возможно, их написали поселившиеся там отшельники. Более того, службы, несомненно, совершались в церкви и в XIV в. - об этом свидетельствует фреска, на которой представлен святой Леонард и которая может быть отнесена к этому времени на основании колористического решения и стиля.

Ключевые слова: Италия; Лацио; долина Суппентония; монашество; аскеизм; пещерные храмы; фрески пещерных храмов.

\section{References}

1. Antonazzi D. Castel S. Elia. Viterbo, Carivit Publ., 1996. 142 p. (in Italian).

2. Barone G. L'incontro tra S. Gregorio Magno e la regina Teodolinda, storia e leggenda. Monachesimo pre-benedettino nella valle Suppentonia: Proceedings of the Conference. Nepi, Antiquaviva Publ., 1999, pp. 26-31 (in Italian).

3. Cati V. Castel Sant'Elia. Natura, storia, arte, religione. Castel Sant'Elia, Comune di Castel Sant'Elia Publ., 1996. 134 p. (in Italian).

4. Cecconi D. Basilica di S. Elia presso Nepi. Cenni storici. Foligno, Stabilimento tipografico F. Salvati Publ., 1890. 23 p. (in Italian).

5. Cignitti B. Leonardo. Bibliotheca Sanctorum, vol 6. Rome, Città Nuova Publ., 1966, pp. 1198-1204 (in Italian).

6. Colafranceschi C. Leonardo: iconografia. Bibliotheca Sanctorum, vol 6. Rome, Città Nuova Publ., 1966, pp. 1204-1208 (in Italian).

7. Degli Effetti A. De' borghi di Roma e luoghi convicini al Soratte con la vita di S. Nonnoso abbate e Tevere navigabile. Rome, Nicolò Angelo Tinassi Publ., 1675. 237 p. (in Italian).

8. Dos Santos F. La decorazione pittorica in una nicchia di Sant'Ermete. Riforma e tradizione 1050-1198. Milan, Jaca Book Publ., 2006, pp. 97-101 (in Italian).

9. Emminghaus J. H. Altare. Enciclopedia dell'Arte Medievale, vol 1. Rome, Treccani Publ., 1991, pp. 436442 (in Italian).

10. Girolami V. Inquadramento territoriale: cenni sull'intervento di consolidamento del costone tufaceo. L'insediamento eremitico ipogeo di S. Leonardo a Castel Sant'Elia. Nepi, Nepigraf Publ., 2013, pp. 26-31 (in Italian).

11. Grisar H. Le tombe apostoliche di Roma. Studi di archeologia e di storia. Studi e documenti di storia e diritto, 1892, vol. 13, pp. 321-373 (in Italian).

12. Hjort O. The First Portrait of St. Benedict? Another Look at the Frescoes of Sant'Ermete in Rome and the Development of a $12^{\text {th }}$ Century Facial Type. Hafnia, 1981, vol. 8, pp. 72-82.

13. Lapponi M. Il monachesimo pre-benedettino e gli insediamenti monastici nella valle Suppentonia. Monachesimo pre-benedettino nella valle Suppentonia: Proceedings of the conference. Nepi, Antiquaviva Publ., 1999, pp. 10-15 (in Italian).

14. Lawrence C. H. Il monachesimo medievale. Forme di vita religiosa in Occidente. Cinisello Balsamo, San Paolo Publ., 1993. 403 p. (in Italian).

15. Lezzani A. La grotta di San Leonardo. Rome, Secreta Publ., 1902. 33 p. (in Italian).

16. Matthiae G.; Gandolfo F. Pittura romana del Medioevo: secoli XI-XIV. Rome, Palombi Publ., 1988. 387 p. (in Italian).

17. Nardini N. La cattedra vescovale di San Tolomeo in Nepi, la pentapoli nepesina et il vero sito degli antichi Veienti, Falisici e Capenati: discorso apologetico. Rome, Angelo Bernabò Publ., 1677. 139 p. (in Italian).

18. Nauclerus J. von. Chronica. Cologne, Gervinus Calenius and Joannes Quentel's heirs Publ., 1579. 1122 p. (in Latin).

19. Osborne J. The Roman Catacombs in the Middle Ages. Papers of the British School at Rome, 1985, vol. 53, pp. 278-328.

20. Paolucci C. M. Gli affreschi della grotta di San Leonardo: descrizione e commento storico critico. L'insediamento eremitico ipogeo di S. Leonardo a Castel Sant'Elia. Nepi, Nepigraf Publ., 2013, pp. 51-59 (in Italian).

21. Paolucci C. M. Pittura rupestre a Castel Sant'Elia nell'eremo di S. Leonardo nei secoli VI-VII. Bollettino Telematico dell'Arte, 2003, no. 319. Available at: http://www.bta.it/txt/a0/03/bta00319.html (accessed July 2013). 
22. Paolucci C. M. Pittura rupestre nell'eremo di S. Leonardo a Castel Sant'Elia. Monachesimo pre-benedettino nella valle Suppentonia: Proceedings of the Conference. Nepi, Antiquaviva Publ., 1999, pp. 14-24 (in Italian).

23. Penco G. Il monachesimo. Milano, A. Mondadori Publ., 2000. 308 p. (in Italian).

24. Penteriani Iacoangeli M. P.; Penteriani U. Nepi e il suo territorio nell'Alto Medioevo: il monachesimo nella Valle Suppentonia (476-1131). Rome, Il calamo Publ., 1999. 180 p. (in Italian).

25. Piazza S. Pittura rupestre medievale: Lazio e Campania settentrionale (secoli VI-XIII). Rome, Ecole française de Rome Publ., 2006. 308 p. (in Italian).

26. Picasso G. Il monachesimo occidentale dalle origini al secolo XI. Dall'eremo al cenobio: la civiltà monastica in Italia dalle origini alletà di Dante. Milano, Libri Schweiller Publ., 1987, pp. 3-63 (in Italian).

27. Ranghiasci Brancaleoni G. Memorie o siano relazioni istoriche sullorigine nome fasti e progressi dellantichissima città di Nepi già territorio falisco e capitale della Pentapoli di Toscana con un succinto ragguaglio in fine di antiche città delle quali si fa cenno nel corso dell'opera divisa in tre distribuzioni. Todi, Raffaello Scalabrini Publ., 1845. 318 p. (in Italian).

28. Raspi Serra J. Insediamenti rupestri religiosi nella Tuscia. Mélanges de l'Ecole Française de Rome. Antiquité, 1976, vol. 88, pp. 27-156 (in Italian).

29. Rohault de Fleury Ch. La messe: études archéologiques sur ses monuments, vol 1. Paris, Morel Publ., 1883. 240 p. (in French).

30. Romano S. Gli affreschi di S. Urbano alla Caffarella: qualche elemento di discussione. Arte medievale, 2012, s. 4, vol. 2, pp. 77-94 (in Italian).

31. Serra R. Il santuario di Santa Maria ad rupes. Rome, Quaracchi Publ., 1899. 283 p. (in Italian).

32. Stendardi A. (ed.) Dialogi libri quattuor Gregorii Magni: Dialoghi. Opere di Gregorio Magno, vol. 4. Rome, Città Nuova Publ., 2000. 495 p. (in Latin and Italian).

33. Zanella A. (ed.) Historia Longobardorum Pauli Diaconi: Storia dei Longobardi. Milano, BUR Publ., 2007. 566 p. (in Latin and Italian).

34. Zuccaro R. Gli affreschi nella Grotta di San Michele ad Olevano sul Tusciano. Rome, De Luca Publ., 1977. 318 p. (in Italian). 


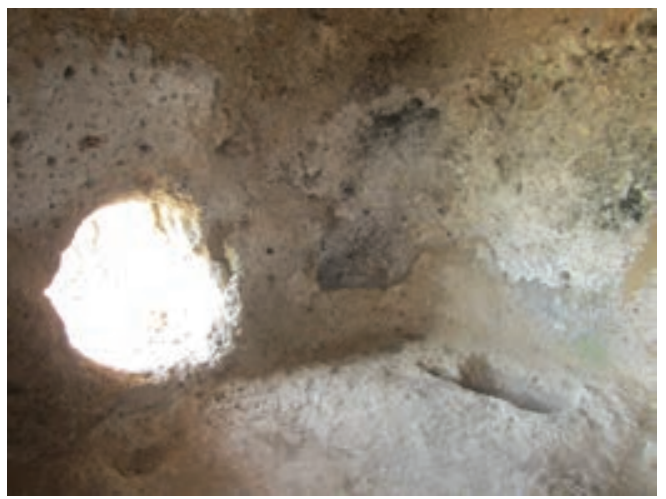

Ill. 84. Grotto of Saint Leonard. Central room, north-west side. Castel Sant'Elia, Viterbo province, Italy

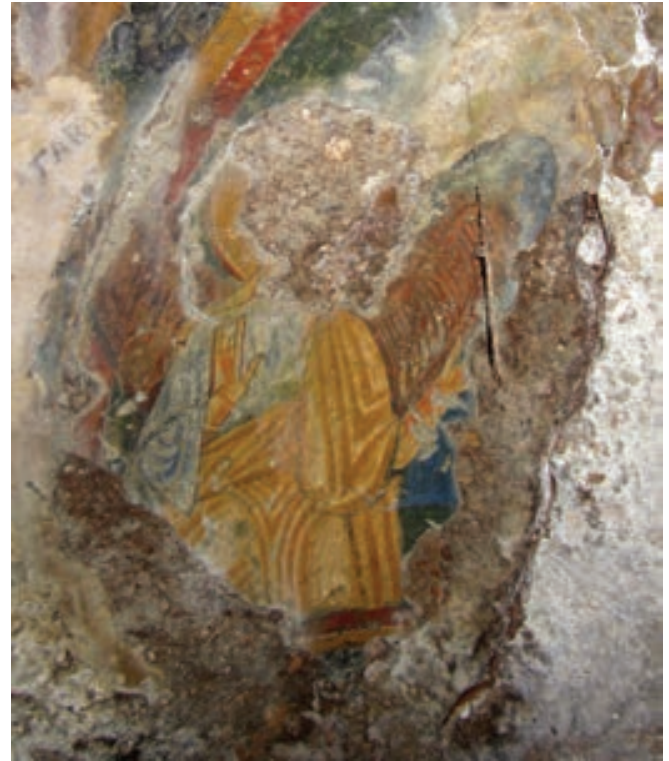

Ill. 86. Angel in the apse. Grotto of Saint Leonard, eastern room, east side. Castel Sant'Elia, Viterbo province, Italy

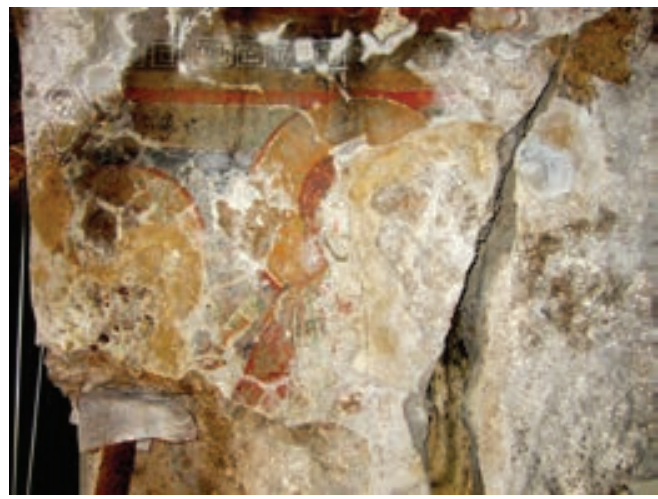

Ill. 85. Detail of the paintings. Grotto of Saint Leonard, eastern room, west side. Castel Sant'Elia, Viterbo province, Italy

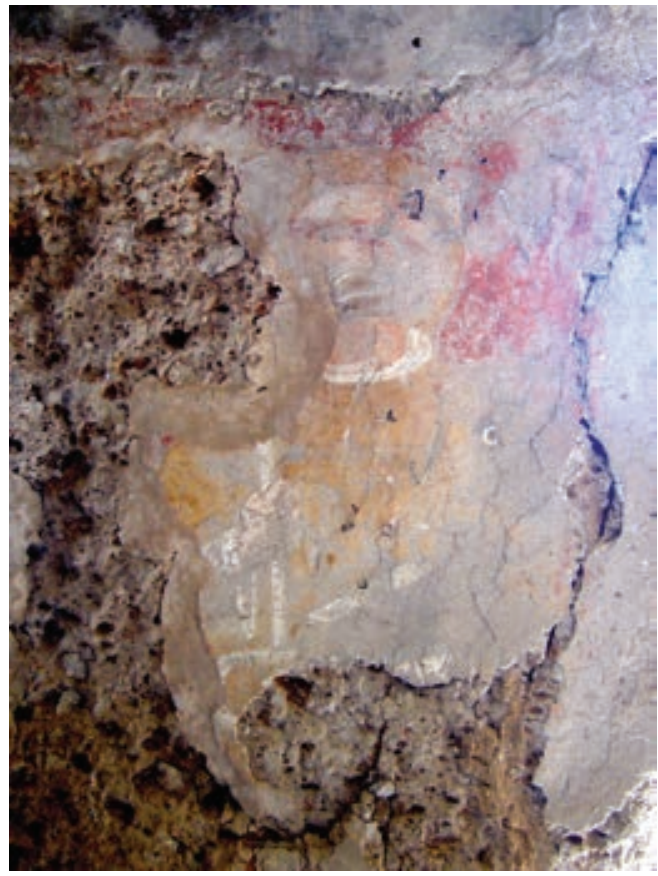

Ill. 87. Panel with Saint Leonard. Grotto of Saint Leonard, eastern room, south side. Castel Sant'Elia, Viterbo province, Italy 